\title{
Dormant forms of Mycobacterium smegmatis with distinct morphology
}

\author{
Aleksey M. Anuchin, ${ }^{1}$ Andrey L. Mulyukin, ${ }^{2}$ Natalya E. Suzina, ${ }^{3}$ \\ Vitaly I. Duda, ${ }^{3}$ Galina I. El-Registan ${ }^{2}$ and Arseny S. Kaprelyants ${ }^{1}$ \\ ${ }^{1}$ Bach Institute of Biochemistry, Russian Academy of Sciences, Moscow, Russia \\ ${ }^{2}$ Winogradsky Institute of Microbiology, Russian Academy of Sciences, Moscow, Russia \\ ${ }^{3}$ Skryabin Institute of Biochemistry and Physiology of Microorganisms, Russian Academy of \\ Sciences, Pushchino, Moscow oblast, Russia
}

Correspondence

Arseny Kaprelyants

arseny@inbi.ras.ru

Received 11 August 2008

Revised 19 December 2008

Accepted 19 December 2008
Cultivation of Mycobacterium smegmatis cells in a nitrogen-limited minimal medium (SR-1) followed by prolonged storage at room temperature without shaking resulted in the gradual accumulation of morphologically distinct ovoid forms characterized by (i) low metabolic activity; (ii) elevated resistance to antibiotics and to heat treatment; and (iii) inability to produce colonies on standard agar plates (non-platable cells). Detailed microscopic examination confirmed that ovoid cells possessed an intact cell envelope, specific fine structure and large electron-transparent bodies in the cytoplasm. Cell staining with Nile red and analysis of the lipid content by TLC revealed the presence of significant amounts of apolar lipids in these bodies. The ovoid forms could be stored for significant periods (up to 5 months) and resuscitated afterwards in a modified Sauton's medium. Importantly, resuscitation of ovoid cells was accompanied by their transformation into the typical rod-shaped cells. We suggest that the observed ovoid cells represent dormant forms, resembling morphologically distinct cells of Mycobacterium tuberculosis previously isolated from tuberculosis patients and infected animals.

\section{INTRODUCTION}

Mycobacterium tuberculosis (MTB), the causative agent of tuberculosis (TB), is responsible for more deaths than any other infectious agent. This organism is estimated to infect about one-third of the world population (Bloom \& Murray, 1992). Nevertheless, $90 \%$ of these 2 billion people remain clinically healthy and never develop overt TB because of quiescent persistence of the tubercule bacilli that they harbour. Such latent TB infections are difficult to diagnose and treat; moreover in adults they can reactivate at any time and are often accompanied by severe destruction of lung tissue (Wallis \& Ellner, 1994). Persisting organisms evidently are in a state of dormancy, defined before as 'a reversible state of low metabolic activity, in which cells can persist for extended periods without division' (Kaprelyants et al., 1993). In recent years, significant progress has been achieved in characterization of various aspects of mycobacterial infection and adaptation to different environmental conditions (Young et al., 2005; Boshoff \& Barry, 2005). However, our knowledge on persisting mycobacteria associated with latent $\mathrm{TB}$ is still very limited, mainly due to presumably very low numbers of such organisms and the lack of clear indication of their

Abbreviations: MTB, Mycobacterium tuberculosis; PI, propidium iodide; TB, tuberculosis. precise localization in living tissues of the host (Neyrolles et al., 2006).

Only a few studies have demonstrated isolation of supposedly dormant MTB cells. Their existence was originally proposed to account for the presence of acid-fast, but transiently 'non-culturable' bacteria in closed pulmonary lesions (Medlar et al., 1952) and further reinforced by interesting findings in the Cornell model of latent TB (McCune et al., 1966). Later, Khomenko and colleagues found filterable or mini-forms of MTB that remained within the tissues of guinea pigs upon the completion of anti-TB treatment. After several months of therapy, viable MTB could no longer be detected by standard plating procedures, although microscopic examination of organ homogenates filtered through $0.2-0.7 \mu \mathrm{m}$ filters revealed the presence of electron-dense forms with a rounded shape and an average diameter of $0.25 \mu \mathrm{m}$. Direct administration of these forms to guinea pigs induced the development of TB, and after several passages, MTB could be isolated by standard culture methods. The authors suggested that these filterable forms might represent persistent organisms, which were able to convert to actively growing cells under the appropriate conditions (Khomenko \& Golyshevskaya, 1984). In the last two decades, significant efforts have been invested to develop several in vitro models of mycobacterial dormancy (reviewed by Young et al., 2005 and Zhang, 
2004). In particular, dormant, 'non-culturable' MTB cells were obtained in vitro in prolonged stationary phase (Sun \& Zhang, 1999; Shleeva et al., 2002). These tubercle bacilli were resuscitated using early-stationary-phase culture supernatant of the same strain (Sun \& Zhang, 1999), and in a later study, by addition of phospholipids or $8 \mathrm{kDa}$ secreted protein found in the supernatant (Zhang et al., 2001). Also, the importance of a family of proteinaceous resuscitation-promoting factors (Rpf) secreted by MTB for resuscitation of 'non-culturable' tubercle bacilli cells was established (Kana et al., 2008). With great anticipation of important findings resulting from these and other studies, it should be admitted that any single model has failed to reproduce the complexity of the in vivo environment and to provide conditions for generation of morphologically distinct persisting cells similar to the forms described by Khomenko's group. In the present study, we attempted to fill this obvious gap in mycobacterial physiology and find requirements essential for production of such forms in vitro.

\section{METHODS}

Strain and growth conditions. Mycobacterium smegmatis strain $\mathrm{mc}^{2} 155$ was routinely maintained on solid medium plates, containing NB (Nutrient Broth, HiMedia Laboratories, India) and 1.5\% agar; only fresh 3-5-day-old colonies were used for production of starter cultures. Cells were grown in standard Sauton's medium or in SR-1 medium of the following composition: glucose, $20 \mathrm{~g} ; \mathrm{MgSO}_{4} .7 \mathrm{H}_{2} \mathrm{O}$, $0.5 \mathrm{~g} ; \mathrm{NaCl}, 0.5 \mathrm{~g} ; \mathrm{KNO}_{3}, 1 \mathrm{~g} ; \mathrm{K}_{2} \mathrm{HPO}_{4}, 0.5 \mathrm{~g} ; \mathrm{CaCO}_{3}, 3 \mathrm{~g} ; \mathrm{H}_{2} \mathrm{O}, 1$ l; pH 7.0 (Krasilnikov, 1950). In some experiments, SR-1 medium was modified by reducing the concentration of $\mathrm{KNO}_{3}$ to $0.2 \mathrm{~g} \mathrm{l}^{-1}$. For c.f.u. estimations, solid NB medium with $1.5 \%$ agar was used. Modified Sauton's medium $\left(\mathrm{KH}_{2} \mathrm{PO}_{4}, 0.25 \mathrm{~g} ; \mathrm{MgSO}_{4} .7 \mathrm{H}_{2} \mathrm{O}, 0.25 \mathrm{~g}\right.$; L-asparagine, $2 \mathrm{~g}$; glycerol, $6 \mathrm{ml}$; ferric ammonium citrate, $0.025 \mathrm{~g}$; sodium citrate, $1 \mathrm{~g} ; 1 \% \mathrm{ZnSO}_{4}, 0.05 \mathrm{ml} ; \mathrm{H}_{2} \mathrm{O}, 1 \mathrm{l} ; \mathrm{pH}$ 7.0) was used for resuscitation of non-platable cells.

Formation of dormant $\boldsymbol{M}$. smegmatis cells. Starter cultures for all experiments were produced by inoculation of one colony of $M$. smegmatis into a $75 \mathrm{ml}$ flask containing $25 \mathrm{ml}$ Sauton's medium, followed by incubation at $37{ }^{\circ} \mathrm{C}$ with agitation (200 r.p.m.) for $35 \mathrm{~h}$. This culture served as the inoculum $(200 \mu \mathrm{l})$ for the second passage under similar conditions. One millilitre of the second-passage culture was transferred to $100 \mathrm{ml}$ nitrogen-limited SR-1 medium in $500 \mathrm{ml}$ flasks, followed by incubation at $30{ }^{\circ} \mathrm{C}$ for $72 \mathrm{~h}$ in a shaker (200 r.p.m.). Then the culture was kept at ambient temperature under stationary conditions (without agitation) for a further 2.5-5 months.

Resuscitation of non-platable cells. Resuscitation of the cultures containing non-platable cells was performed in plastic 48-well microplates (Corning), using the most probable number (MPN) assay as described before (Downing et al., 2005). Briefly, cells $(10 \mathrm{ml}$ of the culture) were centrifuged for $20 \mathrm{~min}, 3000 \mathrm{~g}$ to remove spent medium; the pellets were resuspended and homogenized using a thin syringe needle in $10 \mathrm{ml}$ modified Sauton's medium. The cell suspension was decimally diluted by inoculation of $0.1 \mathrm{ml}$ of cell suspensions into $0.9 \mathrm{ml}$ of the same medium.

Fractionation of morphologically distinct cells of $\boldsymbol{M}$. smegmatis. Two millilitres of the culture was carefully applied onto the top of a 1.1-2.1 $\mathrm{M}$ sucrose gradient (total volume, $8 \mathrm{ml}$ ) in $12 \mathrm{ml}$ glass centrifuge tubes. After centrifugation of the tubes for $60 \mathrm{~min}$ at
$3000 \mathrm{~g}$, the bottom fractions $(120 \mu \mathrm{l})$ were collected and used for c.f.u. estimation and MPN assay.

Incorporation of radioactive tracers. Ten millilitres of 2.5-monthold cell culture, grown in nitrogen-limited SR-1 medium, was centrifuged for $20 \mathrm{~min}, 3000 \mathrm{~g}$. The supernatant was discarded, and the pellet was resuspended in $15 \mathrm{ml}$ modified Sauton's medium for resuscitation. Every $4 \mathrm{~h}$, samples from the resuscitating culture were placed into Eppendorf tubes with $1 \mu \mathrm{l} \mathrm{L}-\left[{ }^{3} \mathrm{H}\right]$ asparagine and $\left[5,6-{ }^{3} \mathrm{H}\right]$ uracyl (each $10 \mu \mathrm{Ci} \mathrm{ml}{ }^{-1} ; 370 \mathrm{kBq} \mathrm{ml}^{-1}$ ) and incubated at $37{ }^{\circ} \mathrm{C}$ with agitation for $4 \mathrm{~h}$. A $0.2 \mathrm{ml}$ sample of the culture was placed into a $15 \mathrm{ml}$ Falcon tube with $3 \mathrm{ml} 10 \%$ ice-cold $\mathrm{CCl}_{3} \mathrm{COOH}$ and incubated at $0{ }^{\circ} \mathrm{C}$ for $15 \mathrm{~min}$. The mixture was then passed through a Whatman glass microfibre filter followed by washing with $3 \mathrm{ml} 10 \% \mathrm{CCl}_{3} \mathrm{COOH}$ and $4 \mathrm{ml} 96 \%$ ethanol. Filters were placed into $10 \mathrm{ml}$ scintillation mixture, and impulse counts were determined using an LS analyser (Beckman Instruments).

Flow cytometry. The FACSCalibur system (Becton Dickinson) was used to measure red fluorescence $(650 \mathrm{~nm})$ of microbial cells after homogenization with a thin syringe needle. This parameter was acquired as pulse height signals for 20000 events at a rate of 800-1100 events per second. Fluorescence was measured before and after treatment of cell suspensions with Nile red $\left(4 \mu \mathrm{g} \mathrm{ml}^{-1}\right)$. Data analysis was done and graphics were acquired using the WinMDI 2.8 software package.

Light and fluorescence microscopy. Cell suspensions were examined under an Eclipse E4000 microscope (Nikon, Japan) in the phase-contrast and epifluorescence modes after staining with propidium iodide (PI, $3 \mu \mathrm{M})$ to detect injured/dead cells, with ethidium bromide $(5 \mu \mathrm{M})$ to identify DNA-containing cells, or with Nile red $\left(4 \mu \mathrm{g} \mathrm{ml}^{-1}\right)$ to detect lipid inclusions; excitation was at $510 \mathrm{~nm}$, and emission was at $>560 \mathrm{~nm}$.

Electron microscopy. Harvested cells were prefixed with $1.5 \%(\mathrm{w} / \mathrm{v})$ glutaraldehyde in $0.05 \mathrm{M}$ cacodylate buffer ( $\mathrm{pH} \mathrm{7.2)}$ ) at $4{ }^{\circ} \mathrm{C}$ for $1 \mathrm{~h}$. After washing three times with this buffer, the material was post-fixed with $1 \% \mathrm{OsO}_{4}$ in $0.05 \mathrm{M}$ cacodylate buffer at $20{ }^{\circ} \mathrm{C}$ for $3 \mathrm{~h}$. After dehydration, the material was embedded in Epon 812 epoxy resin and cut into thin sections on an LKB III ultratome. The sections were mounted on copper Formvar-coated grids and contrasted with a $3 \%$ solution of uranyl acetate in $70 \%$ ethanol for $30 \mathrm{~min}$ and then stained with lead citrate at $20{ }^{\circ} \mathrm{C}$ for $4-5 \mathrm{~min}$. Thin sections were examined in a JEM-100B electron microscope (JEOL) operating under standard conditions at $60 \mathrm{kV}$.

Lipid extraction and analysis. Cells from stationary-phase cultures (Sauton's medium, $72 \mathrm{~h}$ growth) and 3-month stored cultures $(\mathrm{N}$ limited SR-1 medium) of $M$. smegmatis were sedimented by centrifugation $(4000 \mathrm{~g}, 15 \mathrm{~min})$, washed three times in PBS and freeze-dried. Apolar lipids were extracted from $50 \mathrm{mg}$ freeze-dried biomass and analysed by TLC using the solvent system petroleum ether/acetone $(96: 4, \mathrm{v} / \mathrm{v})$ as described by Dobson et al. (1985). Chromatograms were scanned and images were analysed using the TotalLab 2.01 software package.

Antibiotic sensitivity and heat treatment. Four-millilitre aliquots from stationary-phase $(48 \mathrm{~h})$ cultures in Sauton's medium and from cultures stored for 2.5 months in N-limited SR-1 medium were transferred into $15 \mathrm{ml}$ tubes and incubated with different concentrations $\left(25,50,75 \mu \mathrm{g} \mathrm{ml}^{-1}\right)$ of hygromycin or doxycycline at $37^{\circ} \mathrm{C}$ for $24 \mathrm{~h}$ with agitation or heated at $60-80{ }^{\circ} \mathrm{C}$ for $10 \mathrm{~min}$. The number of c.f.u. was determined as described above. PI-positive and negative cells were counted under an epifluorescence microscope using a Helber's chamber. 


\section{RESULTS}

\section{Formation of ovoid forms of M. smegmatis}

Our previous studies on dormant forms of M. smegmatis showed the importance of suboptimal growth conditions for transition of cells to the non-culturable state (Shleeva et al., 2004); therefore, in the present study, we selected the simple, defined SR-1 medium, originally formulated for isolation and cultivation of actinobacteria (Krasilnikov, 1950). This medium supported the growth of M. smegmatis, even though it was less efficient than in Sauton's medium. Thus, after 3 days of cultivation, M. smegmatis cultures reached $10^{10}$ c.f.u. $\mathrm{ml}^{-1}$ in Sauton's medium, $10^{9}$ c.f.u. $\mathrm{ml}^{-1}$ in SR-1, and only $10^{7}$ c.f.u. $\mathrm{ml}^{-1}$ in nitrogen-limited SR-1 medium. M. smegmatis cells were grown in nitrogenlimited SR-1 medium for 3 days, and stored without agitation on a bench at room temperature for a further 5 months.

Periodic examinations of these cultures by phase-contrast microscopy revealed accumulation of atypical cells with significantly altered morphology. After 14 days of incubation, $10-20 \%$ of the cells in the population were rods with easily distinguishable 'bulges' at the cell ends. During further incubation, cells became racket-like, and after 1.5 months, $50-70 \%$ of the cell population was represented by almost round (ovoid) cells with central highly refractive regions (Figs 1 and 2). The percentage of ovoid cells did not change significantly up to 5 months of further incubation. The length to width ratio of these cells was 1.0-1.4 (average diameter $0.8-1.4 \mu \mathrm{m}$ ), in contrast to $5-7$ for stationary-phase cells. The ovoid cells were stainable with Ziehl-Neelsen reagent similarly to stationary-phase, rodshaped cells. The formation of these ovoid cells was absolutely dependent on the conditions of cell cultivation: replacement of nitrogen-limited SR-1 medium by either standard Sauton's medium, its modified versions with different limitations, or normal, unlimited SR-1 medium did not support the accumulation of ovoid cells in prolonged stationary phase. Under those conditions, moribund or dead (according to PI staining) cells appeared with time. The amount of ovoid cells in populations also depended on the age of inoculum used; the maximum yield was obtained with $24 \mathrm{~h}$ inoculum. The storage of cultures without agitation was also a prerequisite for the formation of ovoid cells in sufficient amounts.

\section{Electron microscopy studies}

Electron microscopy of thin sections revealed differences between stationary-phase (Fig. 1e, g) and long-stored $M$. smegmatis cells (Fig. 1f, h). In stationary-phase cells, grown in Sauton's medium, the cell wall exhibited an electrondense layer of murein and an outer loosened layer of low
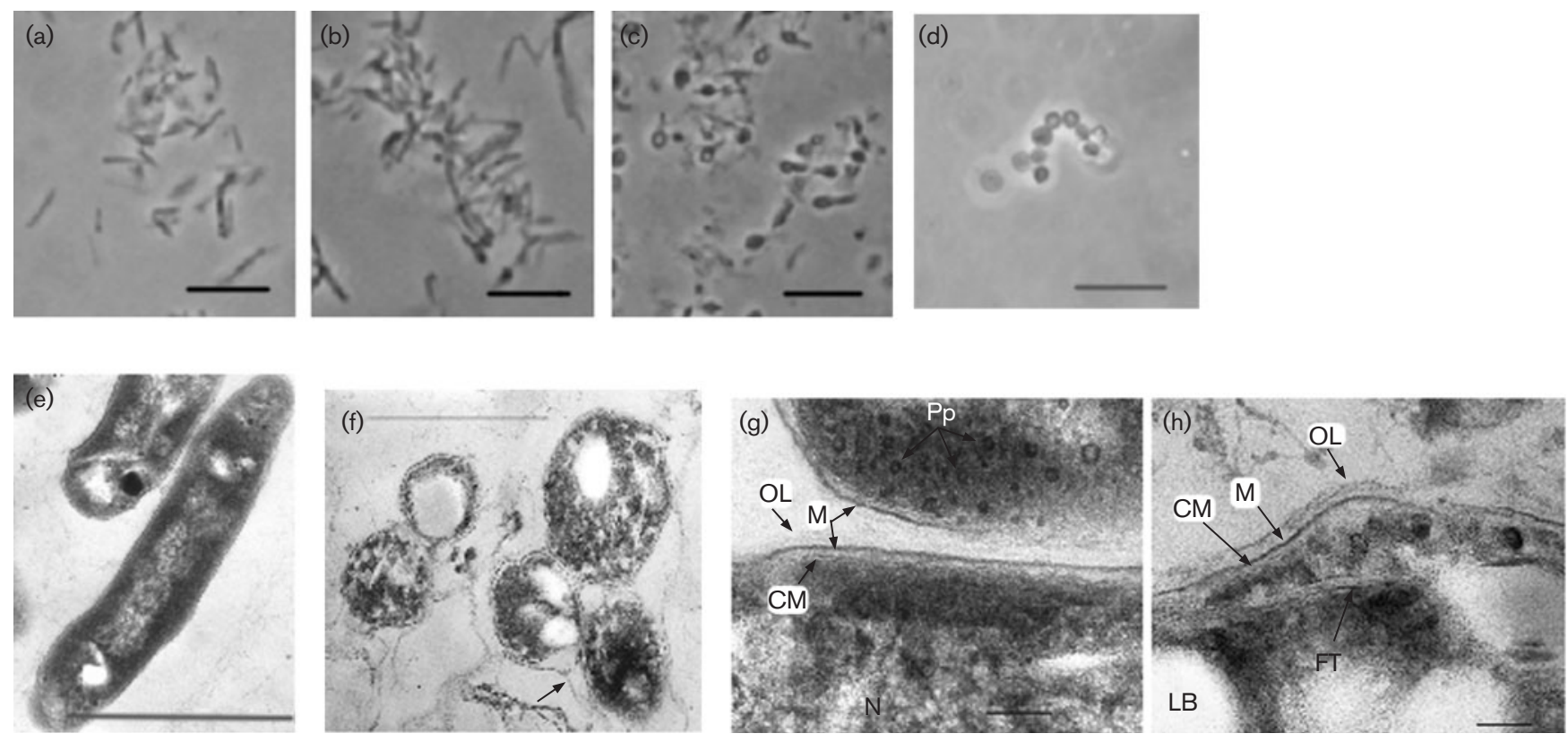

Fig. 1. Light microscopy $(\mathrm{a}-\mathrm{d})$ and thin-section transmission electron microscopy $(\mathrm{e}-\mathrm{h})$ of stationary-phase and ovoid $M$. smegmatis cells. $(a, b, c)$ Cells grown in nitrogen-limited SR-1 medium and stored for 2, 3, 4 weeks respectively or for 5 months $(f, h)$ as described in Methods; (d) pure fraction of ovoid cells obtained after centrifugation in a sucrose gradient. (e, g) Stationary-phase cells (3 days) grown in standard Sauton's medium, under low and high magnification; (f, h) 5-month-old cells under low and high magnification. OL, outer layer of the cell wall; M, murein layer; CM, cytoplasmic membrane; Pp, electrondense granules; N, nucleoid; FT, threads with fibrillar structure; LB, electron-transparent lipid bodies. Bars: (a, b, c, d), $6 \mu \mathrm{m}$; (e, f), $2.0 \mu \mathrm{m} ;(\mathrm{g}, \mathrm{h}), 0.1 \mu \mathrm{m}$. 


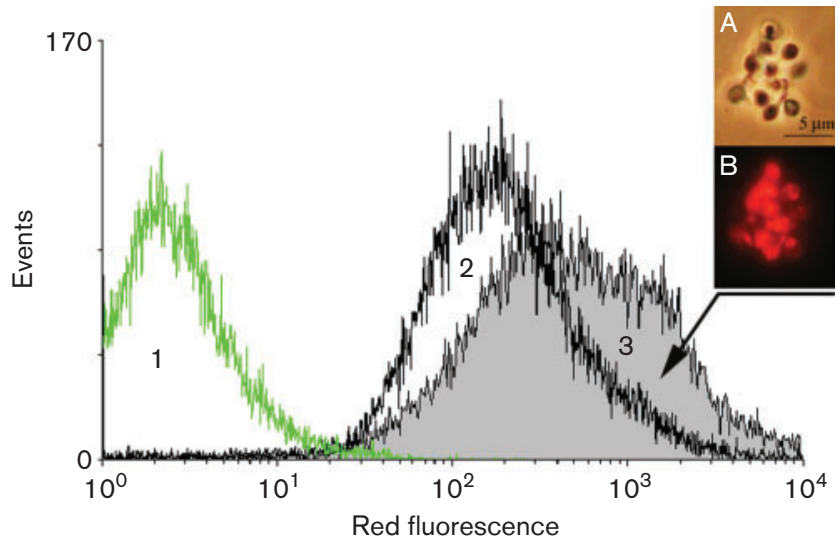

Fig. 2. Flow cytometric analysis of $M$. smegmatis cells. Cells grown in modified SR-1 medium followed by storage for 2.5 months and stationary-phase (52 h) cells grown in Sauton's medium were stained with Nile red $\left(4 \mu \mathrm{g} \mathrm{ml}^{-1}\right)$ and analysed by flow cytometry as described in Methods. The experiment was repeated six times; a typical result is shown. 1, Unstained cells; 2 , stationary-phase cells; 3, 2.5 month stored cells. Inset: phasecontrast microscopy (A) and fluorescence microscopy with Nile red staining $(B)$ of ovoid cells.

electron density (Fig. 1g). The cytoplasm of these cells was electron-dense, homogeneous, finely textured and contained small electron-transparent bodies and abundant electron-dense inclusions similar to polyphosphate granules. The nucleoid with net-like structured electron-dense threads was easily distinguishable in the cytoplasm of stationary-phase cells (Fig. 1g). Similar ultrastructural features were found for $M$. smegmatis in cultures grown to the stationary phase in the nitrogen-limited SR-1 medium (not shown here).

In 5-month-old nitrogen-limited cultures, we observed intact ovoid cells (Fig. 1f, h), which were morphologically distinct from stationary-phase cells. The cell wall contained an additional layer with altered sublayers and an outermost electron-dense layer (Fig. 1h). Some ovoid cells contained an electron-transparent tail-like structure surrounded by the outer layer of cell wall (indicated with an arrow in Fig. 1f). The cytoplasm in ovoid cells was inhomogeneous and coarsly granulated and contained large vesicular and polygonal electron-transparent bodies and small electrondense granules. In some cells, these bodies occupied most of the cytoplasm. Intracytoplasmic fibrillar threads of unknown composition were also observed along the cell's longitudinal axis (Fig. 1h). The nucleoid was poorly visible in ovoid cells.

\section{Fluorescence microscopy and flow cytometry}

Ovoid cells had an intact permeability barrier, as judged from PI staining, after up to 5 months storage, in contrast to rod-shaped cells, which also occurred $(<9 \%)$ in cultures of the same age. To elucidate the nature of the refractive central regions of ovoid cells, we stained the cells with Nile red, widely used for identification of intracellur lipid inclusions (Garton et al., 2002). The inset in Fig. 2 shows that the granules in the majority of ovoid cells indeed showed strong red fluorescence after staining with Nile red. Accordingly, flow cytometry demonstrated a significant fraction of cells $(45 \pm 17 \%)$ with much higher fluorescence in a population of ovoid cells than among stationary-phase cells grown on standard Sauton's medium (Fig. 2). An elevated content of triacylglycerides in ovoid cells was confirmed by TLC analysis of isolated apolar lipids (Fig. 3): the triacylglyceride content per $1 \mathrm{mg}$ dried cell weight was $0.05 \pm 0.006 \mu \mathrm{g}$ for stationary-phase cells and $0.08 \pm$ $0.007 \mu \mathrm{g}$ for ovoid cells.

\section{Culturability of starved $\boldsymbol{M}$. smegmatis cells}

The number of culturable (platable) cells (c.f.u.) gradually decreased with time of storage in the culture grown in nitrogen-limited SR-1 medium; however, the numbers of viable cells estimated by MPN assay were significantly higher than c.f.u. numbers. This difference was more pronounced in older cultures, suggesting the accumulation of cells with a 'non-culturable' (non-platable) phenotype,

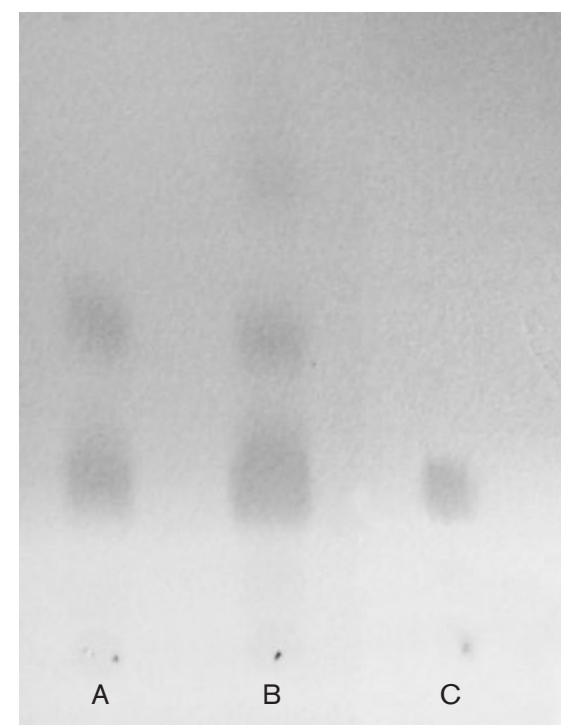

Fig. 3. TLC of M. smegmatis lipids. Stationary-phase cells (48 h or $72 \mathrm{~h}$ incubation) and ovoid cells were obtained as described in the legend to Fig. 2. Apolar lipids were extracted as described in Methods and dissolved in $0.2 \mathrm{ml}$ dichloromethane. One-microlitre samples of lipids isolated from stationary-phase cells $(A)$ or from ovoid cells (B) were applied on TLC plates. Trioleinoyl glycerol $(2.7 \mu \mathrm{g})$ was used as the standard (C). TLC plates were developed in petroleum ether/acetone $(96: 4, v / v)$, dried and stained with iodine vapour. The experiment was repeated four times; a typical result is shown. 


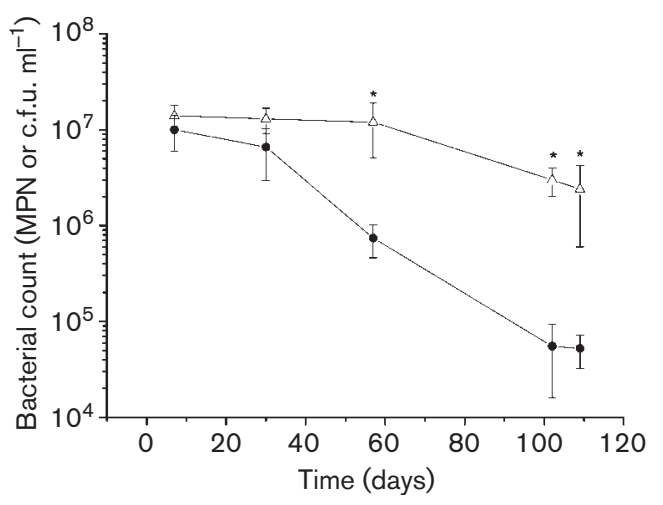

Fig. 4. $M$. smegmatis cells grown in nitrogen-limited SR-1 medium show a partial loss of culturability during storage. Cells were grown and stored, and determinations of MPN $(\triangle)$ and c.f.u. (๑) were done over time, as described in Methods. Each point represents the mean of eight independent experiments; error bars represent SD. Asterisks indicate a significant difference $(P<0.01)$ between c.f.u. and MPN according to Student's $t$-test.

defined by the loss of ability to produce colonies on standard solid media (Fig. 4).

Separation of morphologically distinct rod-shaped and ovoid cells was achieved by centrifugation in a density gradient of sucrose. We found that rod-shaped and most ovoid cells had different buoyant densities, corresponding to $1.6 \mathrm{M}$ and $2.1 \mathrm{M}$ sucrose, respectively. Unlike fully platable, 1.5-month-old stationary-phase cells, grown in Sauton's medium, some ovoid forms were able to pass through $2.1 \mathrm{M}$ sucrose. This difference allowed us to obtain a homogeneous fraction of ovoid cells, which contained no rod-shaped cells according to microscopy (Fig. 1d). In addition, zero c.f.u. or MPN found in the 2.1 M sucrose fraction after centrifugation of 1.5-monthold stationary rod-shaped cells confirmed purity of the ovoid fraction obtained. Some cells in the 'ovoid' population were able to produce colonies on agar plates; however, the majority of them were only able to grow in liquid medium as estimated by MPN assay. For comparison, in a homogeneous population the total number of cells was $2.7 \times 10^{5} \mathrm{ml}^{-1}$, c.f.u. $8 \times 10^{2} \mathrm{ml}^{-1}$ and cells grown in MPN assay $0.55 \times 10^{5} \mathrm{ml}^{-1}$. Thus, more than $99 \%$ of the cells in the pure ovoid cell fraction were non-platable but could be resuscitated in a liquid medium.

\section{Resuscitation of starved cells of M. smegmatis}

Consistent with their dormant phenotype, ovoid forms did not accumulate radioactive precursors of nucleic acid or protein synthesis. However, a substantial increase in uptake of radioactive precursors was observed during resuscitation of such cells in fresh modified Sauton's medium between 0 and $25 \mathrm{~h}$. It preceded the restoration of cell culturability (Fig. 5a), reflecting the importance of activation of cellular metabolism for initiation of cell division. After $25 \mathrm{~h}$ of incubation, the number of c.f.u. rose, accompanied by a significant increase in the incorporation of radioactive precursors (>50000 c.p.m.). The effective 'generation time' calculated from the increase in c.f.u. between 24 and $32 \mathrm{~h}$ was about $1 \mathrm{~h}$, whereas the actual generation time for $M$. smegmatis grown in the same medium was $4 \pm 0.4 \mathrm{~h}$. This difference evidently reflects true resuscitation (restoration of culturability) of cells, whilst the regrowth of initially culturable and resuscitated cells could also contribute to the observed c.f.u. increase. Since maximum restoration of the c.f.u. number after resuscitation could not exceed the MPN $\left(2 \times 10^{7} \mathrm{ml}^{-1}\right)$ for the same culture, it is possible to estimate the restoration period as being no longer than $4 \mathrm{~h}$. However, the first $20 \mathrm{~h}$ of incubation (between 4 and $24 \mathrm{~h}$ ) should also be regarded as an initial resuscitation step.

Microscopic examinations confirmed the conversion of ovoid cells to normal rod-shaped cells during resuscitation (Fig. 5b). Ovoid cells in the pure fraction were also capable of resuscitation and conversion to rod-shaped cells. Analysis of the 16S rRNA sequences of these cells after resuscitation revealed $100 \%$ identity to the initial wild-type of $M$. smegmatis and to cells in the original nitrogenstarved culture.

\section{Sensitivity to stresses}

Dormant forms are known for their remarkable resistance to different stresses. Therefore, we studied the resistance of vegetative and ovoid cells to elevated temperature and antibiotics. Indeed, as compared with 48-h-old stationaryphase cells, the ovoid cells in 2.5-month-old nitrogenlimited cultures were more resistant to high temperature in the range $60-80{ }^{\circ} \mathrm{C}$ (Fig. 6a, b) and to killing by hygromycin and doxycycline as judged by PI staining (Fig. 6c). It is worth mentioning that the rod-shaped cells in these cultures underwent degradation after exposure to 65$70{ }^{\circ} \mathrm{C}$, in contrast to ovoid cells.

\section{DISCUSSION}

We have previously described the formation of 'nonculturable' (non-platable) but resuscitable cells of $M$. smegmatis (Shleeva et al., 2004) and MTB (Shleeva et al., 2002) after prolonged cultivation in stationary phase. Whilst these cells displayed specific features attributed to dormancy, they could persist in this state for only a limited period. Despite the reduction in size, 'non-culturable' cells of both these mycobacterial species did not undergo significant morphological alterations and maintained a rod shape (Shleeva et al., 2004, 2002). In Wayne's model of nonreplicating persistence, MTB cells, grown under microaerophilic conditions, developed a thickened outer cell wall layer. However, the authors did not find any spore-like or ovoid forms in such populations (Cunningham \& Spreadbury, 1998). In the present study, we developed a 
(a)

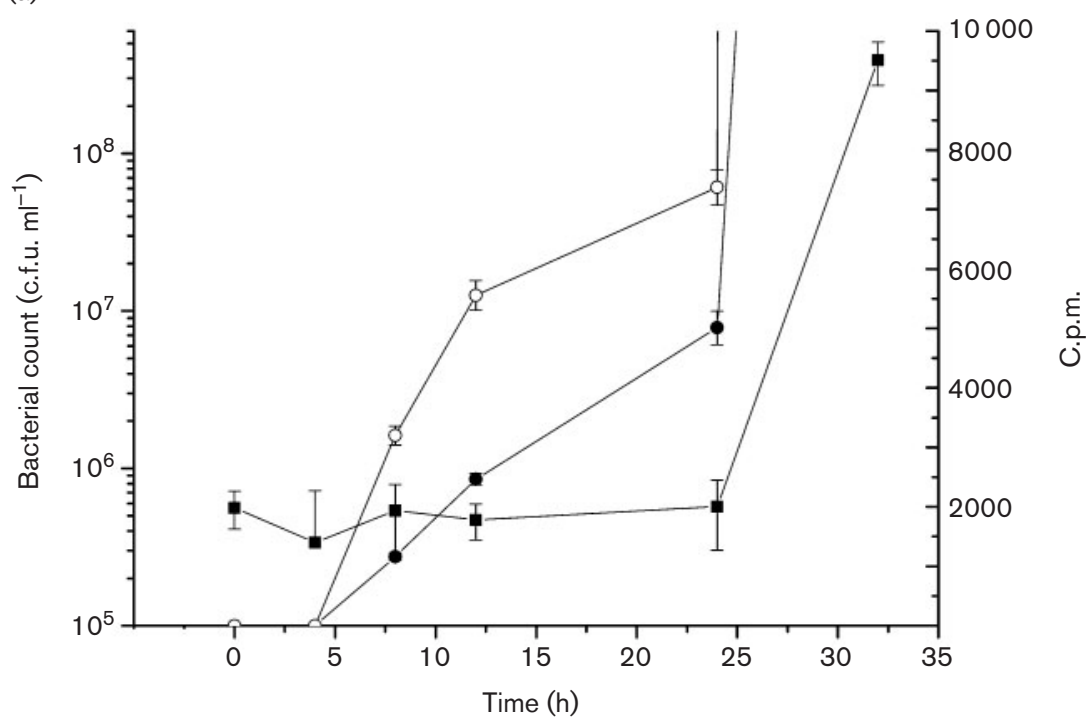

(b)
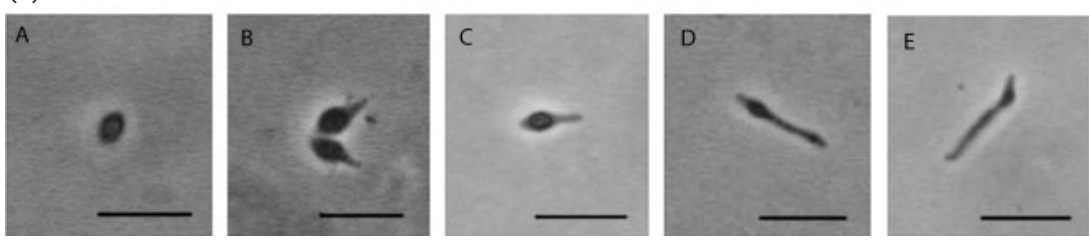

Fig. 5. Resuscitation of ovoid M. smegmatis cells in modified Sauton's medium. A population of ovoid cells, obtained as described in Methods, was washed and inoculated into fresh modified Sauton's medium with further agitation at $37{ }^{\circ} \mathrm{C}$. (b) C.f.u. (ם) and c.p.m. (,$\left[5,6-{ }^{3} \mathrm{H}\right]$ uracyl; $\bigcirc, \mathrm{L}-\left[{ }^{3} \mathrm{H}\right]$ asparagine) were monitored every $4 \mathrm{~h}$ (for more details see Methods). Cell concentration (c.f.u.) after inoculation was $6 \times 10^{5} \mathrm{ml}^{-1}$. This experiment was repeated three times, and the results of a typical experiment are shown. Each point of c.f.u. and c.p.m. determination represents the mean of five and three replicates, respectively; error bars represent SD. (b) Photographs were taken at the time of resuscitation and the percentage of ovoid cells was counted. Cell concentration (c.f.u.) after inoculation was $3.6 \times 10^{6} \mathrm{ml}^{-1}$. A, 0 h; B, 5 h; C, 16 h; D, 20 h; E, 24 h. The percentage of ovoid cells remained at $57 \pm 9 \%$ until $20 \mathrm{~h}$ of resuscitation; it was $44 \pm 10 \%$ at $20 \mathrm{~h}$ and, $21 \pm 6 \%$ at $24 \mathrm{~h}$. No ovoid cells were detected after $25 \mathrm{~h}$ of resuscitation.

procedure for formation of morphologically distinct 'cystlike' cells that were able to persist in the dormant state for prolonged periods. These spherical cells were positively stained by Ziehl-Neelsen reagent and had an intact cell wall with additional envelope structures (identified by electron microscopy); therefore they should not be considered as Lforms, well-documented for mycobacteria isolated from the in vivo environment (Zhang, 2004).

A very low metabolic activity as revealed by the absence of incorporation of radioactive precursors (Fig. 5a), and the resistance to elevated temperatures (Fig. 6a, b) and to antibiotics (Fig. 6c), displayed by ovoid cells further confirmed their similarity to constitutive dormant bacterial cells. Interestingly, ovoid forms were heavily loaded with large lipid inclusions, probably triacylglycerides, according to staining with Nile red and TLC analysis (Figs 2 and 3), as was found for non-replicating MTB cells recovered from sputum (Garton et al., 2002) or for MTB cells persisting in adipose tissue (Neyrolles et al., 2006). The observed correlation between the number of MTB cells containing lipid bodies and the proportion of non-replicating (presumably dormant) cells in sputum samples highlighted the significance of triacylglyceride accumulation for nonreplicating persistence in vivo (Garton et al., 2008).

In contrast to MTB cells, metabolically active M. smegmatis cells are able to produce lipid-inclusion bodies, especially in stationary phase (Garton et al., 2002). Indeed, flow cytometry revealed the ability of stationary-phase cells to be stained with Nile red. However, we observed a major difference in staining pattern between active cells and ovoid forms: the latter contained very large lipid bodies of characteristic form (Fig. 2). In fact, these characteristic lipid bodies together with ovoid morphology could be considered as specific and readily recognizable markers of dormant mycobacterial cells.

It is important that populations of ovoid forms of M. smegmatis contained a significant proportion of non-platable 
(a)

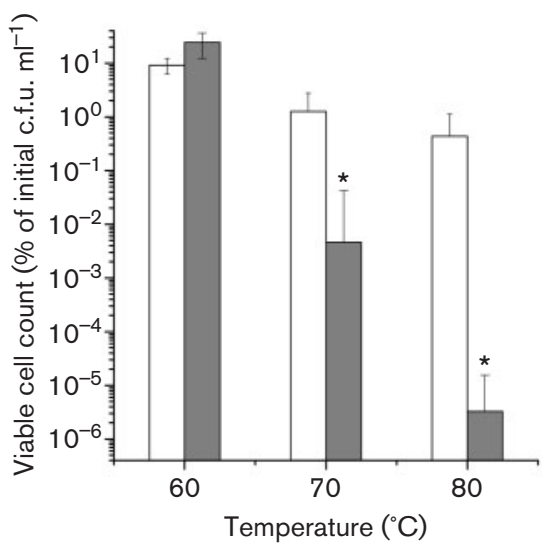

(b)

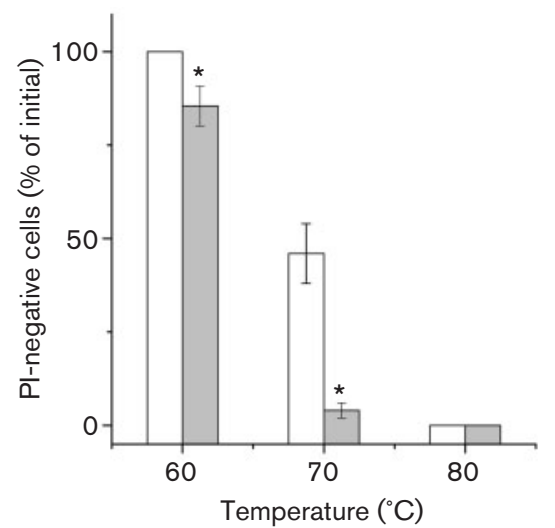

(c)

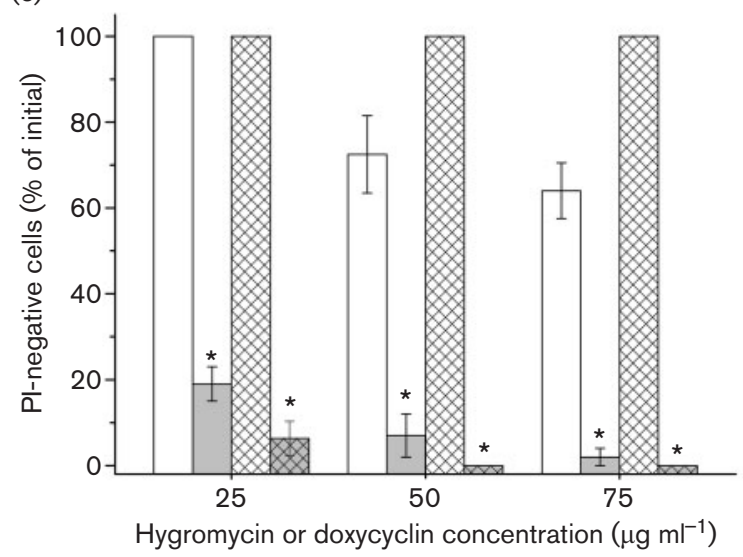

Fig. 6. Sensitivity of M.smegmatis cells to heat or antibiotic treatment. Samples were taken from a 2.5-month-old culture containing ovoid cells (white columns) and from a $48 \mathrm{~h}$ culture grown in standard Sauton's medium (grey columns) and heated at $60-80{ }^{\circ} \mathrm{C}$ for $10 \mathrm{~min}(\mathrm{a}, \mathrm{b})$ or treated with antibiotics (c). (a, b) C.f.u. (a) and PI-negative cells (b) as a percentage of the initial value were determined. Initial c.f.u. for stationary-phase cells and for 2.5 -month-old stored cells were on average $2 \times 10^{9}$ $\mathrm{ml}^{-1}$ and $3 \times 10^{5} \mathrm{ml}^{-1}$, respectively. This experiment was repeated three times; representative results are shown. Each point represents the mean of five replicates for c.f.u. determination and three replicates for percentage of PI-negative cells; error bars represent SD. Asterisks indicate a significant difference $(P<0.01)$ between stationary-phase culture and 2.5-month-old culture containing ovoid cells according to Student's $t$-test. (c) Percentage of Pl-negative cells in populations was determined after $24 \mathrm{~h}$ of incubation with doxycycline (cross-hatched columns) or hygromycin (columns without hatching). This experiment was repeated five times; representative results are shown. Each point represents the mean of three replicates; error bars represent SD. Asterisks indicate a significant difference $(P<0.01)$ between stationary-phase culture and 2.5-month-old culture containing ovoid cells according to Student's $t$-test.

cells (>99\% in 5-month-old cultures), which were able to resuscitate in liquid medium. 'Non-culturable' cells of MTB were found in macrophages (Biketov et al., 2000), in the organs of mice with chronic (but not acute) type of infection (Dhillon et al., 2004) and in Cornell's mouse model of latent TB (Hu et al., 2000). Moreover, the coccoid MTB forms, isolated by Khomenko from infected animal tissues, were also non-platable and required several passages through animals to restore virulence and culturability (Khomenko \& Golyshevskaya, 1984).

Earlier, we concluded that the development of a 'nonculturable' phenotype could be considered as a result of adaptation of mycobacterial cells to cultivation under suboptimal conditions (Young et al., 2005). This conclusion was confirmed in the present study, as the SR-1 medium used supported relatively poor growth of $M$. smegmatis. However, poor growth was an important but not sufficient requirement for the production of ovoid forms, since other non-optimal media did not trigger morphological transformations of $M$. smegmatis cells (Shleeva et al., 2004). Evidently, a combination of different factors (medium composition, nitrogen starvation, agitation regime) should be applied to induce the successful transformation of growing active cells to dormant ovoid forms and switch on as yet unknown mechanisms, 
resulting in dramatic reorganization of cell morphology and cell metabolism. Presumably, such a transformation is a versatile property of many micro-organisms, as cyst-like resting cells of other non-sporulating bacteria (Micrococcus luteus, Arthrobacter globiformis, Pseudomonas aurantiaca) were accumulated during cultivation under nutrient limitations (Suzina et al., 2004). Whilst the molecular mechanisms underlying the formation of ovoid, dormant cells in this study remain unclear, we may hypothesize an important role of ppGpp in this process, as overexpression of the relA gene in $M$. smegmatis resulted in similar morphological transformation. Unfortunately, the authors did not characterize the physiological state of these cells (Ojha et al., 2000).

In conclusion, we suggest that the ovoid forms of $M$. smegmatis found in this study could be considered as specialized dormant forms with a long lifetime (up to 5 months). Because of their similarity to morphologically distinct cells of MTB previously isolated from TB patients (Khomenko, 1987) and infected animals, a comprehensive study of these forms will be important for elucidation of the molecular mechanisms that underlie non-replicating persistence of mycobacteria. Finally, in some experiments, we observed the presence of a few MTB cells morphologically similar to the ovoid forms described in this study, after prolonged incubation in stationary phase (unpublished results). The task for the future is to develop a procedure for production of significant amounts of such MTB forms and to characterize them in detail.

\section{ACKNOWLEDGEMENTS}

We thank Dr Galina Mulamolova and Professor Mike Barer for critical reading of the manuscript and helpful discussions. We also thank Dr Anna Goncharenko for help in 16S rRNA sequencing. This work was supported by the program 'Molecular and Cellular Biology', Russian Academy of Sciences, The Russian Foundation for Basic Research (grants 06-04-49201 and 07-04-12121ofi) and the EU's NM4TB (New Medicines for Tuberculosis) project.

\section{REFERENCES}

Biketov, S., Mukamolova, G. V., Potapov, V., Gilenkov, E., Vostroknutova, G., Kell, D. B., Young, M. \& Kaprelyants, A. S. (2000). Culturability of Mycobacterium tuberculosis cells isolated from murine macrophages: a bacterial growth factor promotes recovery. FEMS Immunol Med Microbiol 29, 233-240.

Bloom, B. R. \& Murray, C. J. L. (1992). Tuberculosis - commentary on a reemergent killer. Science 257, 1055-1064.

Boshoff, H. I. \& Barry, C. E., 3rd (2005). Tuberculosis - metabolism and respiration in the absence of growth. Nat Rev Microbiol 3, 70-80.

Cunningham, A. F. \& Spreadbury, C. L. (1998). Mycobacterial stationary phase induced by low oxygen tension: cell wall thickening and localization of the 16-kilodalton $\alpha$-crystallin homolog. J Bacteriol 180, 801-808.

Dhillon, J. L. D., Lowrie, D. B. \& Mitchison, D. A. (2004). Mycobacterium tuberculosis from chronic murine infections that grows in liquid but not on solid medium. BMC Infect Dis 4, 51 .
Dobson, G., Minnikin, D. E., Minnikin, S. M., Parlett, J. H., Goodfellow, M., Ridell, M. \& Magnusson, M. (1985). Systematic analysis of complex mycobacterial lipids. In Chemical Methods in Bacterial Systematics (Society for Applied Bacteriology Technical Series no. 20), pp. 237265. Edited by M. Goodfellow \& D. E. Minnikin. London: Academic Press.

Downing, K. J., Mischenko, V. V., Shleeva, M. O., Young, D. I., Young, M., Kaprelyants, A. S., Apt, A. S. \& Mizrahi, V. (2005). Mutants of Mycobacterium tuberculosis lacking three of the five $r p f$-like genes are defective for growth in vivo and for resuscitation in vitro. Infect Immun 73, 3038-3043.

Garton, N. J., Christensen, H., Minnikin, D. E., Adegbola, R. A. \& Barer, M. R. (2002). Intracellular lipophilic inclusions of mycobacteria in vitro and in sputum. Microbiology 148, 2951-2958.

Garton, N. J., Waddell, S. J., Sherratt, A. L., Lee, S. M., Smith, R. J., Senner, C., Hinds, J., Rajakumar, K., Adegbola, R. A. \& other authors (2008). Cytological and transcript analyses reveal fat and lazy persister-like bacilli in tuberculous sputum. PLoS Med 5, e75.

Hu, Y. M., Mangan, J. A., Dhillon, J., Sole, K. M., Mitchison, D. A., Butcher, P. D. \& Coates, A. R. M. (2000). Detection of mRNA transcripts and active transcription in persistent Mycobacterium tuberculosis induced by exposure to rifampin or pyrazinamide. J Bacteriol 182, 6358-6365.

Kana, B. D., Gordhan, B. G., Downing, K. J., Sung, N., Vostroktunova, G., Machowski, E. E., Tsenova, L., Young, M., Kaprelyants, A. \& other authors (2008). The resuscitation-promoting factors of Mycobacterium tuberculosis are required for virulence and resuscitation from dormancy but are collectively dispensable for growth in vitro. Mol Microbiol 67, 672-684.

Kaprelyants, A. S., Gottschal, J. C. \& Kell, D. B. (1993). Dormancy in non-sporulating bacteria. FEMS Microbiol Rev 10, 271-285.

Khomenko, A. G. (1987). The variability of Mycobacterium tuberculosis in patients with cavitary pulmonary tuberculosis in the course of chemotherapy. Tubercle 68, 243-253.

Khomenko, A. G. \& Golyshevskaya, V. I. (1984). Filterable forms of Mycobacterium tuberculosis. Z Erkrank Atm Org 162, 147-154.

Krasilnikov, N. A. (1950). Antagonistic Actinomycetes and Antibiotic Substances. Moscow: USSR Academy of Sciences.

McCune, R. M., Feldmann, F. M., Lambert, H. P. \& McDermott, W. (1966). Microbial persistence. I. The capacity of tubercle bacilli to survive sterilization in mouse tissues. J Exp Med 123, 445-468.

Medlar, E. M., Bernstein, S. \& Steward, D. M. (1952). A bacteriologic study of resected tuberculous lesions. Am Rev Tuberc 66, 36-43.

Neyrolles, O., Hernández-Pando, R., Pietri-Rouxel, F., Fornès, P., Tailleux, L., Barrios Payán, J. A., Pivert, E., Bordat, Y., Aguilar, D. \& other authors (2006). Is adipose tissue a place for Mycobacterium tuberculosis persistence? PLoS One 1, e43.

Ojha, A. K., Mukherjee, T. K. \& Chatterji, D. (2000). High intracellular level of guanosine tetraphosphate in Mycobacterium smegmatis changes the morphology of the bacterium. Infect Immun 68, 4084-4091.

Shleeva, M. O., Bagramyan, K., Telkov, M. V., Mukamolova, G. V., Young, M., Kell, D. B. \& Kaprelyants, A. S. (2002). Formation and resuscitation of "non-culturable" cells of Rhodococcus rhodochrous and Mycobacterium tuberculosis in prolonged stationary phase. Microbiology 148, 1581-1591.

Shleeva, M., Mukamolova, G. V., Young, M., Williams, H. D. \& Kaprelyants, A. S. (2004). Formation of "non-culturable" cells of Mycobacterium smegmatis in stationary phase in response to growth under sub-optimal conditions and their Rpf-mediated resuscitation. Microbiology 150, 1687-1697.

Sun, Z. \& Zhang, Y. (1999). Spent culture supernatant of Mycobacterium tuberculosis strain H37Ra improved the viability of 
aged cultures and allowed small inocula to initiate growth in liquid culture. J Bacteriol 181, 7626-7628.

Suzina, N. E., Muliukin, A. L., Kozlova, A. N., Shorokhova, A. P., Dmitriev, V. V., Barinova, E. S., Mokhova, O. N., El'-Registan, G. I. \& Duda, V. I. (2004). Ultrastructure of resting cells of some non-sporeforming bacteria. Mikrobiologiia 73, 516-529.

Wallis, R. S. \& Ellner, J. J. (1994). Cytokine and tuberculosis. J Leukoc Biol 55, 676-681.

Young, M., Mukamolova, G. V. \& Kaprelyants, A. S. (2005). Mycobacterial dormancy and its relation to persistence. In Mycobacterial
Molecular Biology, pp. 265-320. Edited by T. Parish. Norwich: Horizon Scientific Press.

Zhang, Y. (2004). Persistent and dormant tubercule bacilli and latent tuberculosis. Front Biosci 9, 1136-1156.

Zhang, Y., Yang, Y., Woods, A., Cotter, R. J. \& Sun, Z. (2001). Resuscitation of dormant Mycobacterium tuberculosis by phospholipids or specific peptides. Biochem Biophys Res Commun 284, 542-547.

Edited by: M. Daffé 